\title{
Evaluasi Penerapan Metode Request Book sebagai Analisis Kebutuhan Pemustaka di Perpustakaan SMAN Sumatera Selatan
}

\author{
Nurlia $^{1 *}$; M. Syawaludin ${ }^{2}$; Yanto ${ }^{3}$ \\ 1,2,3 Program Studi Ilmu Perpustakaan Fakultas Adab dan Humaniora \\ *Korespondensi: nurlia315@gmail.com
}

\begin{abstract}
This study investigated user's need through the Request Book method in the Library of SMAN Sumatera Selatan. The purpose of this research was to describe user's needs, to describe the application, and to find out the process of books selectionin the school library. This type of research is a descriptive research with a qualitative approach. Data obtained from interview with 10 informants, observations, and documentation. The results of this research showed that the Request Book method was applied to make it easier for librarians in analyzing the needs of users to find out the needs and wants of students for collections available in the library. The results also indicated that the method can help student to find out the book that they need to support their study and want fiction books. With the application of this method, it can increase the rate of borrowed books and students' interest in reading. It was also found that the process of this method application is started by making an announcement, students write the title of the book on a paper, folding the paper and entering it into the Library Suggestion Box, then librarian will listing the title of the book, and the last selecting it and making a list of book that will be bought. The third result indicated that theprocess of book selection is based on six criteria: the author, the title relevant to the school curriculum, price, publisher, year of publication, and best seller books. The tools of selection used are reviews from readers and synopsis of the book that can be found in internet.
\end{abstract}

Keywords : Analysis of User's Needs; Request Book; Library Material Selection

\begin{abstract}
Abstrak
Penelitian ini meneliti mengenai kebutuhan pemustaka melalui Metode Request Book di Perpustakaan SMAN Sumatera Selatan. Tujuan penelitian ini adalah untuk mendeskripsikan kegiatan analisis kebutuhan pemustaka melalui metode Request Book, mendeskripsikan penerapan Request Book, dan mengetahui proses pelaksanaan seleksi bahan pustaka di perpustakaan sekolah. Jenis penelitian ini adalah penelitian deskriptif dengan pendekatan kualitatif. Data didapatkan dari hasil wawancara dengan 10 informan, observasi, dan dokumentasi. Hasil penelitian menunjukkan bahwa metode Request Book diterapkan untuk memudahkan pustakawan dalam melakukan analisis kebutuhan pemustaka yang bertujuan untuk mengetahui kebutuhan dan keinginan siswa akan koleksi yang tersedia di perpustakaan. Dari hasil request dapat diidentifikasi bahwa siswa membutuhkan buku penunjang pembelajaran dan buku fiksi. Dengan diterapkannya metode ini dapat meningkatkan peminjaman buku sehingga sehingga minat baca siswa juga dapat meningkat. Proses pemanfaatannya yaitu dimulai dari perpustakaan yang membuat pengumuman, siswa menulis judul buku di kertas, lipat kertas lalu masukkan ke Library Suggestion Box, pustakawan mendata judul buku, lalu diseleksi dan dibuat daftar pembelian buku. Penyeleksian dilakukan berdasarkan enam kriteria yaitu pengarang, judul yang disesuaikan dengan kurikulum sekolah, harga, penerbit, tahun terbit, dan buku best seller. Alat bantu seleksi yang digunakan yaitu tinjauan/review dan resensi buku yang didapatkan dari internet.
\end{abstract}

Kata Kunci : Analisis Kebutuhan Pemustaka; Request Book; Seleksi Bahan Pustaka

\section{PENDAHULUAN}

Seiring dengan perkembangan Teknologi Informasi Komunikasi (TIK), definisi perpustakaan mengalami perubahan pula. Maka George M. Eberhart mengemukakan bahwa perpustakaan adalah kumpulan sumber daya dalam berbagai format yang ada baik tercetak maupun digital yang diselenggarakan oleh profesional dibidang informasi atau ahli lainnya yang menyediakan akses fisik, digital, bibliografi, akses intelektual yang mudah dijangkau dan didapatkan, serta terdapat beberapa layanan yang ditawarkan dan program yang ditargetkan untuk misi mendidik, menginformasikan, dan rekreasi berbagai khalayak dan bertujuan merangsang pembelajaran individu dan memajukan masyarakat secara keseluruhan (Eberhart, 2006). Semua koleksi yang terdapat di perpustakaan haruslah dikelola, disusun, dan disediakan sesuai dengan kebutuhan informasi penggunanya. 
Kebutuhan informasi pengguna dari berbagai jenis kelompok pembaca, misalnya anak di bawah lima tahun, pelajar, mahasiswa, pekerja, ibu rumah tangga, dan sejenisnya memiliki minat dan kebutuhan bahan bacaan yang berbeda, walaupun subjeknya sama namun disesuaikan dengan tingkat intelektual pembacanya. Dengan perbedaan kebutuhan bahan bacaan inilah akan lahir berbagai jenis perpustakaan dengan koleksi yang sesuai dengan keperluan pembacanya (Purwono, 2014). Salah satu jenis perpustakaan yaitu perpustakaan sekolah.

Perpustakaan sekolah adalah sebuah perpustakaan yang ada di dalam sekolah yang berfungsi sebagai penunjang pelaksanaan program pendidikan (Darmanto, 2018). Perpustakaan sekolah menyediakan berbagai macam koleksi baik tercetak maupun dalam format digital yang dapat menunjang proses belajar mengajar, selain itu koleksi yang disediakan harus relevan dengan keinginan dan kebutuhan siswa di sekolah tersebut. Oleh karena itu, perpustakaan sekolah harus mengetahui kebutuhan pemustakanya sebelum melakukan pembelian buku.

Agar mempermudah pustakawan dalam mengetahui kebutuhan siswa, pustakawan perlu meminta masukan dari siswa, karena siswa sendiri lah yang mengetahui apa yang mereka butuhkan. Melibatkan pemustaka adalah salah satu cara untuk mengetahui kebutuhan mereka. Pemustaka bisa merekomendasikan koleksi yang mereka butuhkan lewat $e$-mail maupun menulis di form yang telah disediakan di perpustakaan (Nusantari, 2012). Kegiatan ini dinamakan dengan analisis kebutuhan pemustaka.

Menurut Stephens dan Franklin, analisis kebutuhan pemustaka adalah proses mengidentifikasi karakteristik pemustaka, dan menilai kebutuhan mereka akan layanan perpustakaan sehingga dapat menentukan buku fiksi dan nonfiksi apa yang akan dibeli (Stephens \& Franklin, 2012). Sedangkan menurut Evans, koleksi perpustakaan harus dikembangkan berdasarkan pemahaman tentang informasi yang dibutuhkan dan diinginkan oleh pemustaka (Evans \& Saponaro, 2005). Kegiatan analisis kebutuhan pemustaka dapat memberikan informasi yang dibutuhkan untuk perencanaan pembelian bahan pustaka yang efektif. Maksudnya, koleksi yang dibeli haruslah sesuai dengan kebutuhan siswa, sehingga tidak akan ada koleksi yang tidak dibaca karena perpustakaan yang baik adalah yang dapat menyediakan dan memenuhi permintaan informasi secara cepat dan tepat (N.S, 2005).

Perpustakaan yang tidak melalukan analisis kebutuhan terlebih dahulu, dikhawatirkan akan ada koleksi yang tidak terpakai karena tidak dibutuhkan oleh pemustaka. Hal ini mengakibatkan terhambatnya pemenuhan kebutuhan informasi pemustaka, sedangkan perpustakaan dapat dikatakan baik apabila dapat memenuhi kebutuhan informasi pemustakanya. Dengan mengetahui kebutuhan pemustaka, maka tujuan perpustakaan dapat tercapai yaitu dapat menyediakan bahan pustaka yang tepat untuk pengguna yang tepat, dan dalam waktu yang tepat pula.

Berdasarkan hasil observasi yang peneliti lakukan di Perpustakaan SMAN Sumatera Selatan, dalam upaya melakukan kegiatan analisis kebutuhan pemustaka yang lebih efektif dan mudah, maka Perpustakaan SMAN Sumatera Selatan menerapkan sebuah metode yang memudahkan pustakawan dalam menghimpun informasi mengenai bahan pustaka yang dibutuhkan dan diinginkan oleh siswa untuk di jadikan koleksi perpustakaan.Selain itu, juga memudahkan siswa dalam menyampaikan kebutuhan mereka atas bahan pustaka. Metode ini diberi nama Request Book. Metode ini sudah diterapkan sejak tahun 2017 atas inisiatif dari kepala perpustakaan yang menjabat saat itu.

Namun, tidak semua judul yang telah ditulis oleh siswa dapat dibeli seluruhnya oleh perpustakaan. Sehingga kepala perpustakaan dan staf perpustakaan harus melakukan penyeleksian dari setiap judul yang telah diberikan oleh siswa, karena untuk menghasilkan koleksi yang berkualitas diperlukan adanya usaha seleksi atau pemilihan judul-judul bahan pustaka yang tepat, terarah, dan sesuai dengan kebutuhan pemustaka. Seleksi bahan pustaka adalah suatu proses 
pengambilan keputusan dalam mengidentifikasi sumber informasi yang di sesuaikan dengan kebutuhan pemustaka (Anderson, 1996).

Selain itu, penyeleksian ini juga dilatarbelakangi oleh anggaran dana yang dimiliki Perpustakaan SMAN Sumatera Selatan sangat terbatas. Sehingga pihak perpustakaan harus selektif dalam memilih bahan pustaka yang memang sesuai dengan kebutuhan dan keinginan siswanya, karena pembelian bahan pustaka yang tidak melalui proses seleksi yang baik menyebabkan perpustakaan membeli koleksi yang out of date, kurang dibutuhkan pengguna, rendahnya jumlah peminjaman atau bisa jadi sudah dimiliki perpustakaan. Semakin lengkap dan sesuai dengan kebutuhan, maka akan semakin banyak peminatnya.

Berdasarkan latar belakang di atas, maka penelitian ini bertujuan untuk mengungkapkan tentang bagaimana usaha Perpustakaan SMAN Sumatera Selatan dalam mengetahui kebutuhan siswanya akan koleksi yang tersedia di perpustakaan, prosedur penerapan Metode Request Book, dan proses pelaksanaan seleksi bahan pustaka terhadap judul-judul yang diberikan oleh siswa.

\section{METODE PENELITIAN}

Metode penelitian pada dasarnya merupakan cara ilmiah untuk mendapatkan data dengan tujuan dan kegunaan tertentu (Sugiyono, 2007). Penelitian ini merupakan penelitian kualitatif. Penelitian kualitatif lebih bersifat deskriptif, di mana data yang dikumpulkan dan disajikan akan berbentuk kata-kata, tidak terfokus pada angka. Data yang telah digunakan ini bertujuan untuk memperoleh pemahaman lebih mendalam tentang sesuatu hal yang diteliti, serta hasil dari penelitian kualitatif akan bersifat deskriptif dari kualitas suatu objek yang diteliti. Pendekatan penelitian yang digunakan ini adalah penelitian fenomenologi. Penelitian fenomenologi digunakan untuk menjelaskan dan mengungkap makna fenomena yang terjadi pada individu disebuah lingkungan atau organisasi (Rahardjo, 2010). Berdasarkan hal ini, maka penelitian ini untuk mengetahui, mengungkap, menjelaskan fenomena yang terjadi di Perpustakaan SMAN Sumatera Selatan terkait dengan kegiatan analisis kebutuhan pemustaka yang melibatkan siswa.

Dalam penelitian ini menggunakan jenis data kualitatif berupa informasi dalam bentuk katakata yang merupakan hasil wawancara kepada para informan untuk memberikan gambaran tentang kegiatan analisis kebutuhan pemustaka melalui metode Request Book di Perpustakaan SMAN Sumatera Selatan. Sumber data yang digunakan ada dua, yaitu sumber primer, adalah data yang diperoleh langsung dari subjek penelitian sebagai sumber informasi pertama. Jadi, sumber data primer dalam penelitian ini didapatkan langsung dari hasil wawancara peneliti kepada kepala dan staf perpustakaan, dan siswa SMAN Sumatera Selatan. Sumber data sekunder adalah data yang bersifat menunjang penelitian dan pelengkap data,diperoleh dari sumber kedua berupa buku, skripsi, jurnal, artikel, laporan, dan literatur lain yang berkaitan dengan masalah dalam penelitian ini.

Dalam penelitian ini, peneliti menggunakan teknik purposive sampling adalah teknik pengambilan sampel sumber data dengan pertimbangan tertentu, misalnya orang tersebut yang dianggap paling tahu tentang apa yang diharapkan peneliti (Sugiyono, 2007). Maka jumlah informan dalam penelitian ini adalah 10 informan. Terdiri dari 1 orang kepala perpustakaan, 1 orang staf perpustakaan, dan 8 siswa kelas 11 dan 12 yang berkunjung ke perpustakaan.

Teknik pengumpulan data ada tiga cara, yaitu observasi, wawancara, dan dokumentasi. Observasi dilakukan dengan cara peneliti mendatangi dan mengamati langsung lokasi penelitian untuk memperoleh data mengenai metode Request Book di Perpustakaan SMAN Sumatera Selatan seperti melihat bentuk fisik dari metode ini, cara menerapkannya, kotak pengumpulannya, serta koleksi yang dimiliki perpustakaan. Teknik wawancara menggunakan wawancara mendalam (in-depth interview), merupakan metode yang digunakan pewawancara untuk bertanya langsung secara tatap muka kepada responden untuk mendapatkan keterangan atau jawaban yang lebih 
jelas, mendalam, mendetail mengenai fenomena yang diteliti (Richard \& Turner, 2008). Dokumentasi adalah teknik yang digunakan untuk mendapatkan informasi yang berhubungan dengan data yang dibutuhkan, baik dokumen yang telah tersedia di lapangan penelitian maupun dokumen yang dibuat oleh peneliti berupa gambar, salinan berkas, video, dan sebagainya (Adib, 2016).

Setelah data terkumpul, maka akan dilakukan analisis data. Teknik analisis data adalah proses menyusun, mengkategorikan data, mencari pola atau tema, dengan maksud untuk memahami maknanya (Nasution, 2002). Analisis data dalam penelitian ini menggunakan Model Miles and Huberman, yang terdiri dari tiga tahap, yaitu reduksi data berarti merangkum, memilih hal-hal pokok, fokus kepada hal penting, dicari tema dan polanya (Sugiyono, 2007). Mereduksi data akan menghasilkan gambaran yang lebih jelas. Dalam penelitian ini, hasil wawancara kepada informan bisa dikatakan melebar dari topik inti penelitian, oleh karena itu, peneliti memfokuskan jawaban hanya pada apa yang peneliti perlukan saja, dengan mengkategorikannya. Penyajian data adalah menyajikan sekumpulan informasi tersusun yang memberi kemungkinan adanya penarikan kesimpulaan dan pengambilan tindakan. Terakhir yaitu penarikan data dan verifikasi, penarikan kesimpulan dilakukan dengan melihat seluruh data yang telah diperoleh selama proses penelitian. Jadi dalam analisis data, peneliti akan merangkum dan menyimpulkan semua informasi yang peneliti dapatkan melalui hasil wawancara, lalu peneliti menginterpretasi kalimat yang sebelumnya menggunakan bahasa informal atau bahasa sehari-hari kedalam bahasa yang lebih baku atau formal agar mudah dipahami.

\section{HASIL DAN PEMBAHASAN}

\section{Analisis Kebutuhan Pemustaka Melalui Metode Request Book}

Dalam usaha untuk mengetahui informasi yang dibutuhkan berupa tersedianya bahan pustaka yang sesuai dengan kebutuhan dan keinginan pemustaka maka Perpustakaan SMAN Sumatera Selatan menerapkan sebuah metode yang disebut dengan Request Book. Latar belakang diterapkannya meotde ini yaitu untuk menghimpun judul-judul buku yang siswa inginkan. Sebagaimana yang telah diungkapkan oleh Ibu Suci Wulandary selaku kepala Perpustakaan SMAN Sumatera Selatan terkait dengan latar belakang dibuatnya request book ini, beliau mengatakan :

"Latar belakang diterapkannya Request Book adalah untuk menghimpun judul-judul buku yang siswa inginkan. Jika dilakukan dengan bertanya secara langsung kepada siswa hal ini sedikit merepotkan staf perpustakaan mengingat siswa yang berjumlah 300 orang. Dengan metode ini memudahkan pihak perpustakaan dan siswa tinggal menuliskan judul buku yang mereka inginkan di secarik kertas. Batas waktu untuk siswa yaitu selama seminggu, sehabis itu baru dibuka dan direkap judul-judul bukunya."

Sama halnya dengan apa yang diungkapkan oleh Ibu Rischa Amelia Sari, selaku Staf Perpustakaan SMAN Sumatera Selatan:

"Request book awalnya dibuat untuk mengetahui kebutuhan siswa, karena siswa meminta buku yang sesuai dengan apa yang mereka butuhkan. Misalnya siswa butuh buku cara bercocok tanam, mereka menginginkan buku itu ada di perpustakaan sehingga mereka merequest nya, jika akhirnya buku tersebut dibeli, mereka pasti akan memanfaatkannya.”

Metode Request Book telah diterapkan dari tahun 2017 atas inisiatif dari Kepala Perpustakaan SMAN Sumatera Selatan sebelumnya yaitu Ibu Yelly Kusnita. Awal diterapkannya metode ini karena tahun 2014 dibawah pimpinan Ibu Yenni Lidyawati, Perpustakaan SMAN 
Sumatera Selatan mendapatkan bantuan dana sebesar 60 juta yang harus dihabiskan dalam satu minggu. Hal ini membuat pihak perpustakaan kebingungan dalam menentukan buku apa yang akan dibeli. Oleh karena itu, pihak perpustakaan meminta bantuan kepada 10 orang asisten perpustakaan (library assistant) untuk memilih buku apapun yang mereka inginkan. Namun, belum tentu buku yang dipilih oleh asisten perpustakaan ini, juga disukai oleh siswa yang lain. Maka pada saat dibawah kepemimpinan Ibu Yelly Kusnita, pembelian buku lebih teratur. Dengan dana 1,5 juta perbulan, koleksi yang dibeli harus sesuai dengan kebutuhan dan keinginan siswa, jadilah diterapkan request book ini sehingga siswa bisa menyampaikan permintaannya kepada perpustakaan.

Jika dilakukan dengan bertanya secara langsung kepada siswa hal ini sedikit memberatkan staf perpustakaan mengingat siswa yang berjumlah 300 orang. Dengan metode ini akan memudahkan pihak perpustakaan dalam mengetahui jenis buku yang dibutuhkan dan diinginkan oleh siswa, selain itu juga memudahkan bagi siswa dalam menyampaikan keinginannya. Menurut Evans dan Saponaro, koleksi perpustakaan harus dikembangkan berdasarkan pemahaman tentang informasi yang dibutuhkan dan diinginkan oleh pemustaka (Evans \& Saponaro, 2005). Sehingga dapat disimpulkan bahwa latar belakang diterapkannya metode request book ini sudah sesuai dengan teori yang dikemukakan oleh Evans dan Saponaro yaitu untuk mengembangkan koleksi nya, perpustakaan harus mengetahui dan mendata judul-judul buku yang dibutuhkan dan diinginkan oleh pemustaka, baik guru dan siswa yang mereka inginkan tersedia di jajaran koleksi perpustakaan, agar koleksinya berdaya guna dan tepat sesuai dengan kebutuhan pemustaka.

Dari hasil request yang telah diterapkan selama hampir dua tahun lebih ini, dapat diketahui bahwa siswa sejatinya membutuhkan informasi yang dapat menunjang kegiatan belajarnya dengan tersedianya buku-buku penunjang pelajaran dan buku kumpulan soal-soal, selain itu siswa juga menginginkan koleksi fiksi khususnya novel yang dapat dibaca oleh siswa untuk mengisi waktu luang nya karena buku-buku fiksi, dengan topik yang ringan dan penggunaan bahasa yang mudah dipahami dapat merelaksasi siswa setelah sehari penuh belajar di kelas.

Judul-judul buku yang telah di rekomendasikan oleh siswa melalui Request Book ini menjadi bahan pertimbangan staf perpustakaan untuk akhirnya dibeli. Jika pada akhirnya buku request-an siswa tersebut dibeli, mereka akan langsung meminjamnya, karena pada akhirnya buku yang mereka butuhkan ada di perpustakaan. Bahkan buku-buku baru tersebut menjadi incaran para siswa, hingga siswa mengantri untuk dapat meminjam dan membacanya. Dari sini dapat dilihat bahwa dengan penerapan metode ini secara tidak langsung, juga dapat memicu peningkatan minat baca siswa. Seperti halnya menurut McColvin, koleksi yang disediakan di perpustakaan harus sesuai dengan permintaan pengguna yang dapat memicu minat baca dan meningkatkan keinginan pemustaka untuk lebih sering meminjam buku (McColvin, 1925).

Maka dapat disimpulkan bahwa manfaat diterapkannya Request Book di Perpustakaan SMAN Sumatera Selatan telah tercapai, hal ini bisa dilihat dari data peminjaman bahan pustaka yang mengalami peningkatan dari dua tahun sebelum diterapkannya Request Book dengan dua tahun setelah adanya request book. Dapat dilihat melalui tabel berikut.

Tabel 4.1

Jumlah peminjaman buku dari tahun 2015-2019

\begin{tabular}{|c|c|}
\hline Tahun & Jumlah peminjaman \\
\hline 2015 & 2982 \\
\hline 2016 & 4350 \\
\hline 2017 & 3893 \\
\hline 2018 & 4702 \\
\hline
\end{tabular}




$$
\begin{array}{|c|c|}
\hline 2019 & 4314 \\
\hline \text { Sumber: Data Statistik Perpustakaan SMAN Sumatera Selatan }
\end{array}
$$

Namun peningkatan ini tidak sepenuhnya meningkat karena adanya request book, karena tidak semua koleksi yang ada di perpustakaan adalah hasil dari request siswa. Request Book hanyalah menjadi jalan atau cara perpustakaan untuk mengetahui kebutuhan siswa, jika kebutuhan nya dipenuhi maka siswa akan langsung meminjam buku tersebut dan hal ini dapat meningkatkan jumlah peminjaman dan minat baca siswa.

\section{Penerapan metode Request Book}

Di Perpustakaan SMAN Sumatera Selatan telah menerapkan sebuah metode dalam merangkum judul-judul buku yang dibutuhkan dan diinginkan oleh siswa. Metode ini disebut dengan Request Book atau dalam Bahasa Indonesia artinya buku permintaan. Maksudnya, siswa dapat meminta ke staf perpustakaan agar dapat menyediakan buku permintaannya tersebut di perpustakaan. Metode Request Book telah diterapkan dari tahun 2017 atas inisiatif dari Kepala Perpustakaan SMAN Sumatera Selatan sebelumnya yaitu Ibu Yelly Kusnita.

Untuk dapat memanfaatkan metode ini, berawal dari pihak perpustakaan terlebih dulu membuat pengumuman melalui selebaran kertas bahwa perpustakaan akan melakukan pembelian buku, informasi ini akan ditempelkan di papan pengumuman yang diletakkan di samping pintu masuk perpustakaan dan diletakkan juga di papan pengumuman sekitar koridor sekolah. Lalu bagi siswa yang ingin merekomdasikan buku keinginannya dapat menuliskannya di secarik kertas (maksimal dua buku) berupa judul buku beserta pengarangnya, jika siswa mengetahui harga buku tersebut, maka harga buku juga dicantumkan. Setelah itu, kertas tersebut dimasukkan ke dalam kotak Library Suggestion Box yang telah disediakan di perpustakaan. Dalam satu bulan, perpustakaan dapat membuka gulungan kertas tersebut, lalu judul-judul buku yang telah ditulis siswa akan dilakukan pendataan. Setelah itu dilakukan pengecekan oleh staf perpustakaan, apakah buku tersebut berdaya guna bagi seluruh siswa ataukah hanya berguna bagi sekelompok siswa saja. Selain itu juga dilakukan penyeleksian berdasarkan beberapa kriteria agar buku yang dibeli benar-benar relevan dengan kebutuhan siswa di SMAN Sumatera Selatan.

\section{Seleksi Bahan Pustaka}

Adapun untuk menghasilkan koleksi yang berkualitas diperlukan adanya usaha seleksi atau pemilihan judul-judul bahan pustaka yang tepat, terarah, dan sesuai dengan kebutuhan pemustaka. Proses seleksi adalah proses mengidentifikasi bahan pustaka yang akan ditambahkan pada koleksi perpustakaan, sehingga proses seleksi menjadi suatu hal yang penting dilakukan oleh staf perpustakaan dalam menentukan bahan pustaka yang akan berakhir pada pembelian (Anderson, 1996). Tidak semua judul yang telah di request oleh siswa berakhir pada pembelian. Staf perpustakaan masih harus melakukan penyeleksian terhadap judul-judul yang telah di rekomendasi oleh siswa.

Sebagaimana yang telah diungkapkan oleh Ibu Suci Wulandary selaku kepala Perpustakaan SMAN Sumatera Selatan terkait dengan proses penyeleksian terhadap judul-judul yang telah di request siswa, beliau mengatakan :

"Ya. Akan dilakukan penyeleksian terhadap judul-judul buku yang di request oleh siswa, karena kita belum tau buku tersebut sesuai atau tidak dengan tujuan perpustakaan. selain itu buku yang direquest harus dipertimbangkan tingkat pemanfaatannya, artinya selain dibaca oleh yang me-request, apakah buku tersebut juga akan dibaca oleh siswa yang lain.” 
Pernyataan ini diperkuat dengan apa yang diungkapkan oleh Ibu Rischa Amelia Sari selaku Staf Perpustakaan SMAN Sumatera Selatan, beliau mengatakan :

“Akan kita seleksi lagi judul-judul buku yang di-request siswa, karena biasanya siswa hanya menulis judul buku tanpa mengetahui informasi yang terkandung di dalam buku tersebut, sehingga nantinya bisa diketahui buku ini akan bermanfaat bagi seluruh siswa atau tidak, jika sesuai kebutuhan maka buku tersebut masuk ke daftar belanja buku."

Menurut American Librarian Assosiation (ALA) seleksi adalah suatu proses pengambilan keputusan dalam mengidentifikasi sumber informasi yang di sesuaikan dengan kebutuhan pemustaka. Sehingga berdasarkan hasil wawancara dan teori tentang seleksi maka penulis menyimpulkan bahwa Perpustakaan SMAN Sumatera Selatan telah melakukan proses penyeleksian yang disesuaikan dengan kebutuhan pemustaka.

Dalam melakukan proses penyeleksian, seorang pustakawan harus memperhatikan beberapa kriteria khusus yang perlu dipertimbangkan seperti (Yulia \& Sujana, 2009) :

a) Judul disesuaikan dengan program lembaga yang ada.

b) Judul disesuaikan dengan tingkatan pengguna.

c) Pengarang sudah sangat terkenal dan ahli/pakar dibidang tertentu.

d) Isi buku harus tahan lama, berbobot, dan tidak cepat berubah.

e) Penerbit cukup terkenal pada bidangnya.

f) Tahun dan edisi terbaru.

g) Harga buku cukup pantas.

Berkaitan dengan kriteria-kriteria tersebut, Perpustakaan SMAN Sumatera Selatan menentukan beberapa kriteria dalam menyeleksi judul buku yang telah di request oleh siswa yaitu pengarang, judul yang disesuaikan dengan kurikulum sekolah, harga, penerbit, tahun terbit, dan buku yang cukup terkenal dikalangan masyarakat atau yang best seller.

Selain itu, dalam pemilihan bahan pustaka diperlukan alat bantu seleksi. Alat bantu seleksi adalah berbagai macam media atau sumber informasi yang dapat dimanfaatkan oleh pustakawan dalam menentukan bahan pustaka yang sesuai dengan kriteria yang telah ditetapkan atau tidak yang pada akhirnya akan dibuatkan keputusan pembelian bahan pustaka yang telah dipilih (Yulia \& Sujana, 2009). Adapun alat bantu seleksi yang digunakan saat proses penyeleksian di Perpustakaan SMAN Sumatera Selatan yaitu tinjauan buku atau Review dan resensi buku yang di cari melalui Internet.

Di samping itu, koleksi juga menilai tingkat pemanfaatannya bagi seluruh siswa bukan hanya untuk sebagian siswa saja, sesuai dengan kebutuhan pemustaka, minat siswa, disesuaikan dengan kurikulum, agar koleksi di perpustakaan berdaya guna bagi seluruh pemustaka. Selain itu juga karena anggaran dana yang dimiliki Perpustakaan SMAN Sumatera Selatan yang terbatas.

\section{SIMPULAN}

Berdasarkan analisis data penelitian yang berjudul "Evaluasi Penerapan Metode Request Book sebagai Analisis Kebutuhan Pemustaka di Perpustakaan SMAN Sumatera Selatan”,maka dapat disimpulkan beberapa hal, yaitu:

1. Kegiatan analisis kebutuhan pemustaka melalui Request Book di Perpustakaan SMAN Sumatera Selatan bertujuan untuk mengetahui kebutuhan dan keinginan siswa akan koleksi yang tersedia di perpustakaan. Dari hasil request dapat diidentifikasi bahwa siswa sejatinya membutuhkan informasi yang dapat menunjang kegiatan belajarnya dengan tersedianya buku-buku penunjang mata pelajaran dan buku bank soal, selain itu siswa juga menginginkan koleksi fiksi yang dapat dibaca oleh siswa untuk mengisi waktu luang. Manfaat yang rasakan 
oleh siswa yaitu melalui request book ini siswa bisa saling berbagi informasi mengenai bukubuku yang bagus untuk dibaca, sehingga hal ini dapat memicu minat baca dan meningkatkan keinginan siswa untuk lebih sering meminjam buku.

2. Proses pemanfaatannya yaitu dimulai dari perpustakaan membuat pengumuman bahwa perpustakaan akan melakukan pembelian buku, informasi ini ditempel di papan pengumuman dekat pintu masuk perpustakaan. Lalu siswa yang ingin memesan buku bisa menuliskan buku yang diinginkannya di kertas kecil, berisi judul buku beserta pengarangnya, dan harga jika diketahui. Setelah itu baru dimasukkan ke dalam kotak Library Suggestion Box atau ke kotak Request Book.

3. Proses penyeleksian terhadap judul-judul buku yang di request oleh siswa dilakukan oleh ketua perpustakaan dan staf perpustakaan langsung. Penyeleksian ini dilakukan karena anggaran dana untuk pembelian buku yang terbatas. Judul buku yang lolos seleksi atau tidak bisa dilihat darienam kriteria yaitu pengarang, judul yang disesuaikan dengan kurikulum sekolah, harga, penerbit, tahun terbit, dan buku yang cukup terkenal dikalangan masyarakat atau yang best seller. Alat bantu yang digunakan yaitu tinjauan atau review dan resensi buku yang didapatkan dari internet.

\section{DAFTAR PUSTAKA}

Adib, H. S. (2016). Metodologi Penelitian. Palembang: Noer Fikri Offset.

Anderson, J. S. (1996). Guide for Written Collection Policy Statements. United States of America: American Library Assosiation.

Darmanto, P. (2018). Manajemen Perpustakaan. Jakarta: Bumi Aksara.

Eberhart, G. M. (2006). The Whole Library Handbook 4: Current Data, Professional Advice, and Curios about Libraries and Library Service. United States of America: The American Library Association. Diambil dari http://paramed.bpums.ac.ir/UploadedFiles/CourseFiles/The_whole_library_handbook9780 838909157-0838909159_682f7799.pdf

Evans, G. E., \& Saponaro, M. Z. (2005). Developing Library and Information Center Collections (Edisi 5). Englewood: Libraries Unlimited.

McColvin, L. R. (1925). The Theory of Book Selection for Public Libraries. London: Grafton.

Nasution, S. (2002). Metode Penelitian Naturalistik Kualitatif. Bandung: Tarsito.

N.S, S. (2005). Tanggung Jawab Perpustakaan dalam Mengembangkan Masyarakat Informasi. Jakarta: Panta Rei.

Nusantari, A. (2012). Strategi Pengembangan Perpustakaan. Jakarta: Prestasi Pustaka.

Purwono. (2014). Perpustakaan dan Kepustakawanan Indonesia. Tanggerang Selatan: Universitas Terbuka. Diambil dari http://repository.ut.ac.id/4106/1/PUST2132-M1.pdf

Rahardjo, M. (2010). Jenis dan Metode Penelitian Kualitatif. Diambil dari https://www.uinmalang.ac.id/r/100601/jenis-dan-metode-penelitian-kualitatif.html

Richard, W., \& Turner, L. H. (2008). Pengantar Teori Komunikasi: Analisis dan Aplikasi. Jakarta: Salemba Humanika. 
Nurlia/Evaluasi Penerapan Metode Request Book sebagai Analisis Kebutuhan Pemustaka di Perpustakaan SMAN Sumatera Selatan

Stephens, C. G., \& Franklin, P. (2012). School Library Collection Development. United States of America: Libraries Unlimited.

Sugiyono. (2007). Metode Penelitian Kuantitatif, Kualitatif dan $R \&$ D. Bandung: Alfabeta.

Yulia, Y., \& Sujana, J. G. (2009). Pengembangan Koleksi. Tanggerang Selatan: Universitas Terbuka. 